\title{
PEMANFAATAN HAK LINTAS KAPAL ASING DI PERAIRAN INDONESIA DAN PENEGAKAN HUKUMNYA
}

\author{
Suharyono Kartawijaya \\ Liaison Officer TNI AL Kodam VII/Wirabuana \\ Jalan Perintis Kemerdekaan Km. 7 Makasar, Sulawesi Selatan \\ E-mail: suharyonokartawijaya@yahoo.co.id
}

\begin{abstract}
This research aims to identify and understand the settings in Indonesian positive law on the use of traffic rights of foreign vessels in Indonesian waters. Related to that,Indonesian waters must be legally protected from the threat of violation of the law as a result of non-compliance with national and international laws and regulations. This research is a normative law approach legislation and the history in which the primary and secondary legal materials were analyzed qualitatively. The results showed that in accordance with applicable positive law, the legislation for law enforcement regarding the utilization of the rights of foreign vessels in Indonesian waters are still using Territoriale Zee en Maritieme Kringen Ordonnantie (TZMKO) or on the Territorial Sea and Maritime Environment 1939 is not in accordance with the UNCLOS 1982. This condition results in law enforcement in the sea that has not run optimally because the legislation has not shown any sectoral harmonization between one another. Recommendations of this research was to implement the harmonization of the laws regulating the use of the rights of foreign vessels traffic law enforcement in realizing optimal in Indonesian waters.
\end{abstract}

Key words: Indonesian waters, the foreign vessel traffic rights, law enforcement

\begin{abstract}
Abstrak
Penelitian ini bertujuan untuk mengetahui dan memahami pengaturan dalam hukum positif Indonesia tentang pemanfaatan hak-hak lintas kapal asing di Perairan Indonesia.Terkait hal tersebut, Perairan Indonesia harus dilindungi secara yuridis dari ancaman pelanggaran hukumsebagai akibat tidak dipatuhinya hukum nasional maupun internasional yang berlaku. Penelitian ini merupakan penelitian hukum normatif menggunakan pendekatan perundangundangan dan sejarah dimana bahan hukum primer dan sekunder dianalisis secara kualitatif. Hasil penelitian menunjukkan bahwasesuai dengan hukum positif yang berlaku, maka peraturan perundang-undangan untuk penegakan hukum mengenai pemanfaatan hak-hak kapal asing di Perairan Indonesia masih menggunakanTerritoriale Zee en Maritieme Kringen Ordonnantie (TZMKO) atau Ordonansi Laut Teritorial dan Lingkungan Maritim tahun 1939 yang sudah tidak sesuai dengan UNCLOS 1982. Kondisi ini berakibat pada penegakan hukum di laut yang belum berjalan dengan optimal karena perundang-undangan sektoral yang ada belum menunjukkan harmonisasi antara satu dengan yang lain. Rekomendasi penelitian ini adalah untuk melaksanakan harmonisasi hukum pengaturan pemanfaatan hak-hak lintas kapal asing dalam mewujudkan penegakan hukum di Perairan Indonesia yang optimal.
\end{abstract}

Kata kunci: perairan Indonesia, hak lintas kapal asing, penegakan hukum 


\section{Latar Belakang}

Berdasarkan pasal 25A Undang-Undang Dasar 1945 Indonesia adalahnegara kepulauan. Sebagai negara kepulauan, Perairan Indonesia yang meliputi Perairan Pedalaman, Perairan Kepulauan dan Laut Teritorial merupakan poros maritim dunia yang menghubungkan berbagai kepentingan dari berbagai bangsa dan negara.Tentang kepentingan ekonomi dunia dapat disebutkan bahwa $80 \%$ bahan baku dan hasil industri Jepang dikapalkan melalui Perairan Indonesia, begitu pula dengan Australia sebagai pengekspor terbesar batubara dan biji besi akan melalui Perairan Indonesia untuk menuju negara pengguna. Lintas melalui Perairan Indonesia akan selalu meningkat terutama kapal-kapal tanker yang mengangkut minyak dari Timur Tengah ke negara-negara Asia yang mengalami pertumbuhan ekonomi tinggi, seperti China, Jepang, Korea Selatan dan Taiwan, dimana lintas yang akan menuju kesana melalui Selat Malaka, Sunda dan Lombok. Untuk kepentingan militer, kapal-kapal perang Amerika Serikat, China, India dan Rusia sangat membutuhkan Perairan Indonesia bagi lintas navigasi dan strategi pertahanan mereka. ${ }^{1}$ Terkait hal ini, Perairan Indonesia harus dilindungi dari ancaman pelanggaran hukumsebagai akibat tidak dipatuhinya hukum nasional maupun internasional yang berlaku.
Sesuai dengan hukum positif yang berlaku, maka peraturan perundang-undangan untuk penegakan hukum mengenai pemanfaatan hak-hak kapal asing di Perairan Indonesia adalah seperti yang terdapat dalam Territoriale Zee en Maritieme Kringen Ordonnantie (TZMKO) atau Ordonansi Laut Teritorial dan Lingkungan Maritim tahun 1939 (Stb. 1939 Nomor 442).

Pasal 1 ayat (1) angka 1 sampai dengan angka 4-nya tentang ketentuan kewilayahan, karena bertentangan dengan praktek dan pandangan hidup bangsa Indonesia, yaitu konsepsi kewilayahan berdasarkan wawasan nusantara, telah dicabut dan diganti dengan Undang-Undang Nomor 4 Prp. Tahun 1960 tentang Perairan Indonesia. Begitu pula dengan Pasal 2 sampai dengan Pasal 8 telah dicabut dan dinyatakan tidak berlaku lagi dengan undang-undang dibidang perikanan. Sementara untuk pasal 9 dan pasal-pasal seterusnya yang mengatur tentang aspek fungsi-fungsi kelautanbeserta sanksi pidananya masih tetap berlaku sampai saat ini. Peraturan produk Pemerintah Hindia Belanda ini diberlakukan dahulu hanya mengutamakan kesamaanhukum (asas konkordansi)antara Indonesia sebagai "overzees gebiedsdeel" dengan negeri Belanda dalam lingkungan "Het Koninkrijk der Nederlanden", daripadakepentingan integritet territorial daripada Indonesia sebagai suatu negara kepulauan. ${ }^{2}$ Oleh karena Belanda menganut

1 Sahono Subroto et al, Konvensi PBB tentang Hukum Laut, Sebuah Tinjauan, Surya Indah Jakarta, 1983, hlm. 62.

2 Kusumaatmadja Mochtar, Bunga Rampai Hukum Laut, Bina Cipta, Jakarta, 1978, hlm. 7. 
lebar laut teritorial sejauh 3 (tiga) mil laut diukur dari garis pantainya, yang kemudian berdasarkan concordant principle juga diberlakukan di Hindia Belanda (sekarang: Indonesia) ${ }^{3}$ seperti ditetapkan dalam Pasal 1 TZMKO 1939.

Namunketentuan TZMKO 1939 ini, untuk masa kini dengan berlakunya United Nations Convention on the Law Of the Sea 1982 (UNCLOS 1982), sudah tidak dapat lagi menjadi pedoman bagi permasalahan di laut yang sangat kompleks dan mempunyai implikasi pelanggaran hukum. Berbagai insiden dapat dikemukakan sebagai contoh, misalnya penutupan Selat Sunda dan Selat Malaka,penegakan hukum pemanfaatan hak lintas damai oleh kapal ferry berbendera Portugis, Lusitania Expresso pada tahun $1992^{4}$ dan pemanfaatan hak lintas alur laut kepulauan Indonesiaoleh armada tempur Amerika Serikat yang menyebabkan terjadinya Insiden Bawean, atau konsekuensi dari adanya alur laut tersebut yang dibuka untuk pelayaran internasional yang menurut Pasal 27 San Remo Manual bahwa didalam keadaan perang alur-alur laut itu mau tidak mau harus dijadikan daerah yang dinetralisir. ${ }^{5}$

Republik Indonesia telah meratifikasi Konvensi Perserikatan Bangsa-Bangsa tentang Hukum Laut tersebut dengan Undang-undang Nomor 17 Tahun 1985tentang Pengesahan
"United Nations Convention on the Law Of the Sea". Sebagai konsekuensi maka peraturan perundang-undangan mengenai aspek kewilayahan maupun mengenai aspek fungsi-fungsi kelautan yang telah ada perlu diharmoniskan agar sesuai dengan ketentuan Konvensi PBB tersebut.

Ketentuan UNCLOS 1982 ini mengatur rezim-rezim hukum laut secara lengkap dan menyeluruh, yang rezim-rezimnya satu sama lain tidak dapat dipisahkan. ${ }^{6}$ Ketentuan ini tentu saja berakibat yuridis bahwa menggantungkan pelaksanaan UNCLOS 1982 dari undang-undang sektoral adalah tidak mungkin.

Sebagai tindak lanjut dari UNCLOS 1982, Indonesia telah menetapkan beberapa perundang-undangan sektoral, baik mengenai aspek kewilayahan, seperti undang-undang perairan maupun fungsi-fungsi kelautan, seperti undang-undang pelayaran, namun perundang-undangan tersebut satu sama lain tidak menampakkan keharmonisan.

Meskipun ratifikasi Indonesia terhadap UNCLOS 1982 belum diikuti dengan peraturan pelaksanaannya, kenyataannya adalah bahwa di Indonesia dewasa ini dapat dikatakan terdapat pengaturan yang rangkap terhadap obyek-obyek yang sama, dalam bentuk peraturan perundang-undangan yang mengatur berbagai aspek hukum laut yang

3 I Wayan Parthiana, Pengantar Hukum Internasional, Mandar Maju, Bandung, 2003, hlm. 153.

4 Hikmat Israr, Laksamana Agus Suhartono Dari Blitar ke Cilangkap, Budaya Media, 2013, Bandung, hlm. 50.

5 Kusumaatmadja Mochtar, Bunga Rampai Hukum Laut, Op.cit., hlm. 154.

6 Penjelasan atas Undang-undang Nomor 17 Tahun 1985 tentang Pengesahan UNCLOS 1982. 
telah ada selama ini (sejak tahun 1960). Gambaran diatas menunjukkan adanya ketidakharmonisan dalam pengaturan hak lintas kapal asing di wilayah laut Indonesia, yaitu pengaturan oleh hukum nasional yang telah ada selama ini dan pengaturan oleh hukum internasional yang telah menjadi hukum nasional sebagai akibat ratifikasi tersebut diatas. $^{7}$

Kondisi disharmoni ini lebih banyak disebabkan karena terlalu banyaknya peraturan perundangan yang mengatur Perairan Indonesia.Penerapan berbagai macam peraturan perundang-undangan yang mengatur Perairan Indonesia secara bersama-sama tanpa upaya harmonisasi atau penyelarasan dan penyesuaian sudah tentu menimbulkan masalah seperti penegakan hukumnya.

Konvensi Hukum Laut PBB 1982 ini jelas mengandung banyak perubahan dan pembaharuan terutama yang menyangkut yurisdiksi Indonesia di laut dan sekaligus bertalian juga dengan hak-hak warga negara Indonesia di laut. ${ }^{8}$ Oleh karenanya peraturan mengenai pemanfaatan hak lintas kapal asing dan penegakan hukum di Perairan Indonesia seperti yang terdapat dalam Territoriale Zee en Maritieme Kringen Ordonnantie Tahun 1939 tersebut perlu diganti untuk terciptanya keharmonisan.
Berdasarkan uraian di atas, maka permasalahan dalamtulisanini adalah:

a. Apakah pengaturan pemanfaatan hak-hak lintas kapal asing di Perairan Indonesia sudah diatur secara harmonis?

b. Mengapa dalam hukum positif yang mengatur pemanfaatan hak-hak lintas kapal asing di Perairan Indonesia belum diatur secara harmonis?

Penelitian ini merupakan penelitian hukum normatif. Pendekatan penelitian dilakukan melalui pendekatan sejarah (historical approach) untuk memahami filosofi dari aturan hukum dari waktu ke waktu. ${ }^{9}$ Selain itu pendekatan juga dilakukan melalui pendekatan perundang-undangan (statute approach) yang bersangkut paut dengan pemanfaatan hak lintas kapal asing di Perairan Indonesia.

Adapun bahan hukum sebagai sumbersumber penelitian diambil dari:

1. Bahan hukum primerberupa perundang-undangan, yaitu perjanjian internasionalberupa Konvensi Hukum Laut Perserikatan Bangsa Bangsa (United Nations Convention on the Law Of the Sea) 1982 dan beberapa hukum positif, yaitu (1) Territoriale Zee en Maritieme Kringen Ordonantie 1939, (2) UndangUndang Nomor 17 Tahun 2008 tentang Pelayaran, (3) Undang-Undang Nomor 43 Tahun 2008 tentang Wilayah Negara,

7 Naskah lengkap UNCLOS 1982 telah dilampirkan pada UU No.17 Tahun 1985 dengan demikian menjadi bagian dari undang-undang tersebut.

8 Etty R.Agus, Konvensi Hukum Laut 1982, Abardin, Bandung, 1991, hlm. 238.

9 Peter Mahmud Marzuki, Penelitian Hukum, Kencana Prenada Media Group, Jakarta, 2013, hlm. 166. 
(4) Peraturan Pemerintah Nomor 36 Tahun 2002 tentang Hak dan Kewajiban Kapal Asing Dalam Melaksanakan Hak Lintas Damai Melalui Perairan Indonesia, dan (5) Peraturan Pemerintah Nomor 37 Tahun 2002 tentang Hak dan Kewajiban Kapal dan Pesawat Udara Asing Dalam Melaksanakan Hak Lintas Alur Laut Kepulauan Melalui Alur Laut Yang Ditetapkan.

2. Bahan hukum sekunder yaitu semua publikasi tentang hukum yang bukan merupakan dokumen resmi meliputi buku-buku teks dan kamus hukum.

Bahan-bahan hukum yang telah dikumpulkan dan diinventarisasi kemudian diolah dan dikaji secara mendalam sehingga diperoleh gambaran yang utuh mengenai persoalan hukum yang diteliti.Bahan-bahan hukum yang telah diperoleh dalam penelitian ini akan dianalisis secara kualitatif dengan memberikan gambaran-gambaran (deskripsi) dengan kata-kata atas temuan-temuan. ${ }^{10}$

\section{Pembahasan}

\section{A. Sejarah Penegakan Hukum di Perairan Indonesia}

\section{Periode sebelum proklamasi kemerdekaan 17 Agustus 1945}

Nenek moyang bangsa Indonesia sejak zaman dahulu kala terkenal sebagai para pelaut yang sudah mengarungi lautan ke segala penjuru dunia, terbukti dari peninggalanpeninggalan purbakala di berbagai tempat. Beberapa etnis yang unggul antara lain etnis Sangihe/Talaud, Madura, Buton, Bugis dan Makassar. Etnis Bugis Makassar terkenal dengan perahu pinisinya sampai ke seluruh dunia.

Dari praktik dan perilaku yang terus berlangsung secara turun temurun dengan memanfaatkan laut di sekitar, di tengah-tengah, ataupun di antara pulau-pulau dari kepulauan nusantara, dapat disimpulkan bahwa nenek moyang bangsa Indonesia tidak memandang laut sebagai pemisah antara pulau ataupun antara etnis, tetapi memandang sebagai sarana mempersatukan seluruh kepulauan nusantara. Dengan demikian, laut itu pun dipandang tidak terpisahkan dengan daratan dan tanah dibawahnya dari pulau-pulau ataupun dari ruang udara diatas laut serta daratan tersebut. Ketiganya dipandang sebagai satu kesatuan yang saling menguatkan yang dikenal dengan sebutan tanah air. Akan tetapi, berapa batas luar dari bagian laut yang merupakan tanah air memang tidak ditegaskan oleh setiap etnis yang mendiami nusantara.

Keadaan seperti tersebut diatas, berlangsung hingga bangsa Portugis memasuki kepulauan nusantara dari sebelah Barat dan Spanyol dari sebelah Timur, karena tertarik dengan kekayaan alam yang berlimpah. Kemudian disusul oleh Belanda yang pertama kali datang berdagang di Nusantara pada tahun

10 Salim HS, Penerapan Teori Hukum Pada Penelitian Tesis dan Disertasi, RajaGrafindo Persada, Jakarta, 2013, hlm. 19. 
1596 dan menjelma menjadi penjajah. Selama masa penjajahan tersebut laut nusantara lebih banyak berfungsi sebagai alat pemisah.

Liga Bangsa-Bangsa pada tahun 1930 menyelenggarakankonferensi kodifikasi hukum internasional di Den Haag, dimana salah satu agendanya adalah menetapkan lebar laut teritorial. Namun ternyata konferensi ini gagal mencapai kata sepakat dalam menetapkan lebar laut teritorial, sehingga masing-masing negara memberlakukan lebar laut teritorial sesuai klaim masing-masing. ${ }^{11}$ Kegagalan untuk mencapai kata sepakat tentang lebar laut teritorial ini menyebabkan kandasnya usaha Liga Bangsa-Bangsa untuk mengadakan kodifikasi hukum mengenai yurisdiksi maritim.

Barulah pada tahun 1939 (menjelang Perang Dunia II) pemerintah Hindia Belanda menentukan batas laut teritorialnya dengan menetapkan Territoriale Zee en Maritieme Kringen Ordonnansi (TZMKO) Stb. Nomor442 tahun 1939 atau Ordonansi tentang Laut Teritorial dan Lingkungan Maritim. Berdasarkan Pasal 1 Ordonansi ini, lebar laut teritorial adalah 3 mil laut yang diukur berdasarkan garis pangkal normal, yaitu garis pangkal yang ditetapkan pada pantai pada waktu air laut surut dengan mengikuti arah atau lekukan pantai tersebut. Dalam peraturan di zaman Hindia Belanda tersebut, pulaupulau di wilayah nusantara dipisahkan oleh laut di sekelilingnya. Ini berarti kapal-kapal asing bebas melayari laut yang memisahkan pulau-pulau tersebut.

Tampaknya, pemerintah Hindia Belanda hanya menyelaraskan(concordant) lebar laut teritorialnya dengan lebar laut teritorial Belanda. Hal ini sesuai dengan asas konkordansi yang merupakan politik hukum Belanda atas wilayah jajahannya.

Pada periode ini TZMKO 1939 digunakan sebagai sarana peraturan untuk melakukan penegakan hukum guna melindungi wilayah perairan Hindia Belandadari pelanggaran, seperti misalnya: larangan kapal asing untuk melakukan pengintaian, pemotretan, mengumpulkan bahan-bahan keterangan (Pasal 9) dan larangan bagi kapal asing yang tanpa alasan sah melakukan lego jangkar atau tinggal mengambang (Pasal 10).

\section{Periode setelah proklamasi kemerdekaan sampai konferensi hukum laut PBB I/1958}

Setelah Indonesia merdeka pada 17 Agustus 1945, sesuai prinsip Uti Possidetis, bahwa wilayah laut Indonesia merupakan warisan wilayah laut Hindia Belanda.

Pada periode ini, atas dorongan Menteri Veteran, Chairul Saleh kepada Mochtar Kusumaatmadja untuk mengubah status hukum Laut Jawa dari laut bebas menjadi laut pedalaman,akhirnya lahirlah Prinsip Negara Kepulauan (archipelagic state principle) dengan Mochtar Kusumaatmadja sebagai konseptor. ${ }^{12}$ Prinsip tersebut kemudian oleh Pemerintah Indonesia dikeluarkan dalam 
bentuk Pengumuman Pemerintah pada tanggal 13 Desember 1957 yang ditandatangani oleh PM. Djuanda Kartawijaya sehingga terkenal sebagai Deklarasi Djuanda. Deklarasi ini tidak dapat dilepaskan dari peristiwa disintegrasi bangsa di tanah air yang terjadi ditahun 1957 , dimana presiden mengumumkan keadaan darurat perang pada tanggal 14 Maret 1957 , kemudian menjadi keadaan perang pada tanggal 17 Desember 1957. Deklarasi Djuanda selain tertuju kepada kekuatan asing (sengketa dengan Belanda mengenai pengembalian Irian Barat) juga sekaligus upaya untuk melakukan penataan wilayah kedaulatan negara. Lalu lalang kapal-kapal Belanda di wilayah perairan RI mencapai puncaknya dengan dikirimkannya kapal induk Hr. Ms. Karel Doorman ke Irian Barat melalui Laut Jawa untuk "show of force". ${ }^{13} \mathrm{Hal}$ ini dapat terlihat dari teks pernyataan pemerintah maupun pertimbangan yang menjadi dasar tindakan tersebut bahwa segi keamanan dan pertahanan merupakan aspek yang penting sekali dalam kebijaksanaan pemerintah mengenai perairan Indonesia ini. ${ }^{14}$

Pada periode ini, sarana peraturan tentang penegakan hukum untuk melindungi wilayah Indonesia (daratan dan perairan pedalaman) setelah Deklarasi Djuanda tahun 1957 masih mempergunakan kaidah-kaidah TZMKO 1939 berdasarkan Pasal II Aturan Peralihan UUD 1945 yang pada intinya menyatakan bahwa segala hukum yang berlaku pada masa sebelum disahkannya UUD 1945, masih tetap berlaku sepanjang tidak bertentangan dengan UUD 1945. Pemberlakuan pasal ini dimaksudkan untuk menghindari terjadinya kekosongan hukum.Demikian pula setelah digantinya UUD 1945 dengan Konstitusi RIS 1949, Stb tersebut masih tetap berlaku berdasarkan Pasal 192 ayat (1) dan (2), demikian pula setelah 18 negara RIS dibubarkan dan diganti dengan NKRI dengan UUD Sementara 1950, berdasarkan Pasal 142, Stb tersebut juga masih tetap berlaku.

\section{Periode setelah konferensi hukum laut PBB I/1958 sampai konferensi hukum laut PBB II/1960 dan III/1982}

Kegagalan konferensi hukum laut PBB I/1958 dan II/1960 dalam mencapai kata sepakat mengenai lebar laut teritorial berarti menimbulkan status quo.Oleh karenanya Indonesia menegaskan klaim sepihaknya dalam Deklarasi Djuanda dengan memberlakukan Undang-Undang Nomor 4 Prp 1960 tentang Perairan Indonesia, yang isinya sangat sederhana karena hanya 4 (empat) pasal yang menyatakan bahwa lintas damai tidak boleh membahayakan kedaulatan dan keselamatan negara, tanpa rincian apa yang dimaksud dengan kegiatan yang membahayakan itu.

13 Nina Pane, Rekam Jejak Kebangsaan Mochtar Kusuma-Atmadja, Op.cit., hlm. 46. 14 Mochtar Kusumaatmadja, Hukum Laut Internasional, Bina Cipta, Bandung, 1986, hlm. 188. 
Untuk memperkuat Undang-Undang Nomor 4 Prp tahun 1960 tentang Perairan Indonesia, Indonesiamenerbitkan Peraturan Pemerintah No. 8 Tahun 1962 tentang lalu lintas damai kendaraan asing dalam perairan Indonesia, yang merupakan penegasan bagi petugas-petugas dilaut tentang perairan apa saja diakui adanya hak lintas damai. ${ }^{15}$ Sarana penegakan hukum masih menggunakan TZMKO 1939 oleh karena Undang-Undang Nomor 4 Tahun 1960 hanya mencabut Pasal 1 dari Staatblad ini.

\section{Periode konferensi hukum laut PBB III/1982 sampai sekarang}

Periode sesudah berlakunya Konvensi Hukum Laut PBB III/1982hingga saat sekarang ini(2015), pemerintah sudah membuat beberapa undang-undang sektoral antara lain undang-undang tentang pelayaran dan undang-undang tentang wilayah negaraserta undang-undang kelautan. Namun undang-undang sektoral atau fungsional yang selama ini diberlakukan ternyata belum memuat ketentuan UNCLOS 1982 sebagaimana mestinya.

Oleh karenanya pada periode inipun karena kaidah-kaidah UNCLOS 1982 belum dilaksanakan, berarti belum ada hukum positif yang menggantikan kedudukan laranganlarangan yang terdapat dalam Territoriale Zee en Maritieme Kringen Ordonnansi (TZMKO) tersebut.

\section{B. Macam-Macam Hak Lintas Kapal Asing}

UNCLOS 1982 telah memberikan seperangkat ketentuan yang mengatur hak lintas kapal asing di perairan suatu negara. Terdapat setidaknya 3 (tiga) jenis hak lintas, yaitu lintas damai, lintas transit dan lintas alur laut kepulauan.

\section{Hak Lintas Damai (The Right of Innocent Passage)}

Pada zaman dahulu laut dipandang sebagai entitas yang tidak dimiliki siapapun (res nullius), dan karena itu setiap negara dapat memanfaatkannya untuk apapun, contohnya berlayar atau mencari nafkah. Barulah ketika status hukum atas laut dipersoalkan, akhirnya melahirkan pranata hukum laut, yakni laut teritorial dan laut lepas. Laut teritorial merupakan bagian dari kedaulatan negara sehingga tidak ada kebebasan berlayar bagi kapal-kapal asing, sedangkan laut lepas yang bukan kedaulatan suatu negara masih tetap diakui adanya kebebasan berlayar (freedom of navigation). Namun hal ini menimbulkan masalah, sebab ketiadaan kebebasan berlayar di laut teritorial terutama untuk tujuan perdagangan dan lalu lintas orang, mengakibatkan mengalami kendala yang pada akhirnya akan merugikan negaranegara itu sendiri. Untuk mengatasi masalah ini, ditempuh jalan tengah, yakni laut teritorial tetap merupakan wilayah dan kedaulatan 
negara pantai, tetapi bagi kapal-kapal asing diberikan hak untuk berlayar. Hak inilah yang kemudian dikenal dengan sebutan hak lintas damai. Hak ini kemudian diakui, diterima, dihormati dan dipraktekkan secara luas serta dirasakan sebagai kaidah hukum oleh semua negara. Dengan kata lain, hak lintas damai sudah menjadi hukum kebiasaan internasional dalam bidang hukum laut.

Pengaturan tentang hak lintas damai dalam UNCLOS 1982 dapat dilihat dalam Bagian 3 (Pasal 17-26) yang terbagi menjadi tiga sub bagian, yakni peraturan yang berlaku bagi semua kapal, peraturan yang berlaku bagi kapal dagang dan kapal pemerintah yang dioperasikan untuk tujuan komersial dan peraturan yang berlaku bagi kapal perang dan kapal pemerintah lainnya yang dioperasikan untuk tujuan non komersial. Selanjutnya Pasal 19 UNCLOS 1982 memberikan pengertian mengenai lintas damai. Lintas adalah damai sepanjang tidak merugikan bagi kedamaian, ketertiban atau keamanan negara pantai.

Mengenai hak lintas damai, Indonesia telah mengundangkan Undang-Undang Nomor 6 Tahun 1996 tentang Perairan Indonesia dan Peraturan Pemerintah Nomor 36 Tahun 2002 tentang Hak dan Kewajiban Kapal Asing dalam Melaksanakan Hak Lintas Damai melalui Perairan Indonesia.

Berdasarkan Undang-Undang Nomor 6 Tahun 1996 tentang Perairan Indonesia, komponen lintas damai hanya dua. Pertama, kapal yang melintasi laut (perairan kepulauan atau laut teritorial) tanpa melintasi perairan pedalaman atau menghubungi pelabuhan atau fasilitas pelabuhan diluar perairan pedalaman. Kedua, kapal yang melanjutkan ke atau dari perairan pedalaman atau singgah di pelabuhan tersebut atau fasilitas pelabuhan. ${ }^{16}$ Selama dalam pelayaran, kapal asing itu harus berlayar terus menerus, langsung, serta dalam tempo yang secepat mungkin. Meskipun demikian, berhenti ataupun membuang jangkar dapat dibenarkan sepanjang ada alasan yang lazim berlaku dalam dunia pelayaran.

Negara pantai memiliki hak untuk menangguhkan/melarang lintas damai di bagian tertentu dari wilayah laut, meskipun hanya untuk sementara. Hak untuk penangguhan ini mengacu pada ketentuan UNCLOS 1982 yang pada hakikatnya harus didasarkan pada alasan keamanan dan keperluan latihan militer dengan menggunakan senjata yang melibatkan negara pantai.

Indonesia pada tahun 1992 pernah memberlakukan pelarangan atas lintas damai untuk pelayaran kapal ferry Lusitania Expresso yang berkebangsaan Portugal berlayar dari Lisabon menuju Dili. ${ }^{17}$ Pemerintah Indonesia menyatakan bahwa pelayaran kapal tersebut yang membawa penumpang dari Australia adalah tidak damai dan tidak akan mentolerir setiap pelanggaran terang-terangan hukum nasional atau hukum internasional oleh sekelompok orang yang menyatakan niat 
mereka untuk masuk ke Indonesia tanpa mematuhi hukum yang ada dan dengan maksud untuk memprovokasi.

Jika kapal perang asing yang berlayar di laut teritorial berdasarkan hak lintas damai ternyata tidak menaati peraturan perundangundangan yang dikeluarkan oleh negara pantai mengenai lintas damai serta mengabaikan permintaan negara pantai, maka negara pantai dapat meminta supaya kapal perang itu segera meninggalkan laut teritorialnya. ${ }^{18}$ Dalam hal ini kepada negara pantai diberikan kebebasan apakah akan meminta supaya kapal perang asing itu meninggalkan laut teritorialnya ataukah membiarkan saja pelanggaran yang dilakukan oleh kapal perang tersebut. Ini nampak dari penggunaan kata "dapat meminta" (may require),yang cukup realistis, mengingat kekuatan angkatan bersenjata negara-negara di dunia sangat berbeda, yang dalam banyak hal berhubungan erat dengan tingkat kemajuan negara yang bersangkutan.

\section{Hak Lintas Transit (The Right of Transit Passage)}

Masalah hak lintas ini muncul terutama setelah adanya perluasan yurisdiksi negara atas laut dalam bentuk perluasan laut teritorial dari 3 (tiga) mil laut menjadi 12 (dua belas) mil laut. Sebagai akibatnya selat-selat strategis yang tadinya merupakan bagian dari laut bebas, kini menjadi bagian dari laut teritorial suatu negara. Rezim baru ini disampaikan oleh delegasi Inggris pada tahun 1974 sebagai sebuah perumusan jalan tengah atau kompromi antara rezim lintas damai dan proposal kebebasan pelayaran yang diajukan oleh kelompok yang disebut sebagai kelompok negara selat di satu sisi dan Amerika Serikat serta Uni Soviet di sisi lainnya. ${ }^{19}$ Istilah lintas transit terletak diantara kebebasan pelayaran(freedom of navigation) dan lintas damai.

Hak lintas transit bagi kapal asing dapat dilakukan di selat yang digunakan untuk pelayaran internasional (strait used for international navigation). Bab III UNCLOS 1982 menyebutkan penggunaan selat untuk pelayaran internasional, tetapi tidak memberikan kriteria khusus bagaimana untuk menentukan selat yang digunakan untuk pelayaran internasional. Konvensi hanya mendefinisikan hak dan kewajiban kapal dan pesawat udara serta negara yang berbatasan dengan selat. Pasal 38 UNCLOS 1982 memberikan definisi lintas transit yang pelintasannya terdiri dari tiga elemen yaitu, (a) lintas transit adalah penggunaan kebebasan pelayaran dan penerbangan; (b) pelintasannya harus hanya untuk tujuan transit tanpa berhenti, langsung dan cepat; (c) pelaksanaanya harus sesuai dengan aturan UNCLOS 1982 yang membahas tentang selat yang digunakan untuk pelayaran internasional. Lintas transit adalah hak untuk semua kapal dan pesawat untuk melewati selat yang digunakan untuk 
pelayaran internasional. Tidak ada batasan pada jenis kapal dan pesawat serta kebangsaan kapal dan pesawat, mereka memiliki kebebasan pelintasan yang sama.

Indonesia belum mempunyai peraturan perundang-undangan khusus yang mengatur tentang lintas transit di Perairan Indonesia atau selat yang digunakan untuk pelayaran internasional di wilayah Indonesia. Hanya ada Undang-Undang Nomor 6 Tahun 1996 tentang Perairan Indonesia, yang membahas lintas transit di wilayah Indonesia. Pasal 20 dari undang-undang ini menyatakan bahwa "semua kapal dan pesawat udara asing bebas berlayar atau terbang hanya semata-mata untuk tujuan transit tanpa pemberhentian, langsung dan secepat mungkin melalui laut teritorial Indonesia di selat antara satu bagian dari laut lepas atau zona ekonomi eksklusif Indonesia dengan bagian lain dari laut lepas atau zona ekonomi eksklusif Indonesia”. Pasal 21 ayat 2 undang-undang ini juga mengatur bahwa regulasi lebih lanjut atas penggunaan lintas transit akan diatur dalam peraturan pemerintah, namun hingga tahun 2015 belum ada peraturan pemerintah tersebut.

\section{Hak Lintas Alur Laut Kepulauan (The Right of Archipelagic Sea Lane Passage)}

Hak lintas alur laut kepulauan didefinisikan dalam Pasal 53 ayat 3 UNCLOS 1982 sebagai berikut:

“...hak pelayaran dan penerbangan dengan cara normal yang hanya dapat digunakan untuk transit yang terus menerus, langsung, dan tidak terhalang dari satu bagian laut bebas atau ZEE dan bagian laut lepas atauZEE lainnya".

Berdasarkan ketentuan tersebut, alur laut kepulauan seperti bentuk hak lintas lainnya (lintas damai dan lintas transit) merupakan hak dari kapal dan pesawat udara asing untuk melintas dengan cara normal(normal mode) secara terus menerus, langsung dan tidak terhalang dari satu bagian laut bebas atau ZEE dan bagian laut bebas atau ZEE lainnya. Apabila negara kepulauan tidak menetapkan alur laut kepulauan, maka hak lintas alur laut kepulauan dapat dinikmati oleh kapal dan pesawat udara asing di rute yang biasa digunakan untuk pelayaran internasional.

Indonesia telah menetapkan lintas alur laut kepulauan. Penetapan ini telah diatur lebih lanjut dalam peraturan perundangundangan Indonesia antara lain UndangUndang Nomor 6 Tahun 1996 tentang Perairan Indonesia, Undang-Undang Nomor 17 Tahun 2008 tentang Pelayaran, Peraturan Pemerintah Nomor 37 Tahun 2002 tentang Hak dan Kewajiban Kapal dan Pesawat Udara Asing Dalam Melaksanakan Hak Lintas Alur Laut Kepulauan Melalui Rute yang Telah Ditetapkan, Peraturan Pemerintah Nomor 5 Tahun 2010 tentang Kenavigasian dan Petunjuk Pelaksanaan Panglima TNI tentang Pengamanan Alur Laut Kepulauan Indonesia. Alur laut kepulauan Indonesia terdiri dari3 (tiga) alur Utara-Selatan yang disebut dengan: 
Alur Laut Kepulauan Indonesia I, Alur Laut Kepulauan II, dan Alur Laut Kepulauan Indonesia III. Alur Laut Kepulauan Indonesia I mempunyai dua cabang yaitu I dan IA yang menghubungkan dari/ke Laut China Selatan dan Selat Singapura ke Samudera Hindia melalui Selat Sunda dan Selat Karimata. Alur Laut Kepulauan Indonesia II ditujukan untuk memfasilitasi pelayaran/penerbangan dari Laut Sulawesi, Perairan Filipina dan Samudera Pasifik dari/ke Samudera Hindia dengan melewati Selat Makasar dan Selat Lombok. Alur Laut Kepulauan Indonesia III mempunyai beberapa cabang sebagai jalur pelayaran/penerbangan dari Laut Timor dan Laut Arafura ke Samudera Pasifik melalui Laut Sawu, Laut Banda, Laut Seram dan Laut Maluku.

Permasalahan nyata terkait dengan perbedaan penafsiran dan penerapan dari rute lintas normal (normal passage route) dan pelaksanaan hak lintas alur laut kepulauan dapat disimak dengan terjadinya Kasus Bawean (disebut kasus Bawean karena terjadi di atas Pulau Bawean, Jawa Timur) atau Insiden Hornet. ${ }^{20}$

\section{Identifikasi Disharmoni Hukum Pemanfaatan Hak-Hak Lintas Kapal Asing}

Potensi terjadinya disharmoni hukum tercermin dalam beberapa peraturan yang berhubungan dengan pemanfaatan hak-hak lintas kapal asing di Perairan Indonesia, yaitu:

\section{Territoriale Zee en Maritieme Kringen Ordonnantie 1939}

Berdasarkan Pasal 1 Ordonansi ini, lebar laut teritorial ditetapkan sejauh 3 mil laut yang diukur berdasarkan garis pangkal normal, yaitu garis pangkal yang ditetapkan pada pantai pada waktu air laut surut dengan mengikuti arah atau lekukan pantai tersebut. Dalam peraturan di zaman Hindia Belanda tersebut, pulau-pulau di wilayah nusantara dipisahkan oleh laut bebas disekelilingnya. Ini berarti kapal-kapal asing bebas melayari laut yang memisahkan pulau-pulau tersebut.

Ordonansi 1939 digunakan sebagai sarana peraturan untuk melakukan penegakan hukum guna melindungi wilayah perairan Hindia Belanda dari pelanggaran, seperti larangan bagi kapal asing untuk melakukan pengintaian, pemotretan, mengumpulkan bahan-bahan keterangan (Pasal 9) dan larangan bagi kapal asing yang tanpa alasan sah melakukan lego jangkar atau tinggal mengambang (Pasal 10), yang bagi pelanggarnya diancam pidana dengan hukuman kurungan selama-lamanya 3 (tiga) bulan atau denda sebanyak-banyaknya lima ratus rupiah.

Sebahagian besar pasal-pasal Ordonansi ini telah dicabut oleh Undang-Undang Nomor 4 Tahun 1960 dan Undang-Undang Perikanan.

\footnotetext{
20 Disebut insiden Hornet karena melibatkan pesawat tempur F-18 Hornet AL AS yang terbang dan mendarat dari kapal induk USS Carl Vinson.Dalam insiden ini TNI AU melibatkan pesawat tempur F-16 yang take off dari Pangkalan Udara TNI AU Madiun.
} 


\section{Undang-undang Nomor 17 Tahun 2008 tentang Pelayaran}

Undang-Undang ini mencabut dan menyatakan tidak berlaku Undang-Undang Pelayaran Nomor 21 Tahun 1992. Ruang lingkup berlakunya undang-undang ini juga berlaku untuk semua kapal asing yang berlayar di Perairan Indonesia. Terdapat tiga jenis hak lintas kapal asing sebagaimana yang diatur dalam UNCLOS 1982, akan tetapi undang-undang pelayaran ini hanya mengatur satu jenis saja yaitu hak lintas alur laut kepulauan. Tidak ada penjelasan resmi mengapa hanya mengatur hak lintas alur laut kepulauan saja. Seharusnya dalam undangundang ini mengatur keseluruhan hak lintas dimaksud, sebab lintas-lintas yang lain juga mengatur tentang lintas kapal.Dalam pasal 194 ayat 3 yang mengatur tentang hak lintas kapal asing disebutkan bahwa semua kapal asing yang menggunakan alur laut kepulauan Indonesia dalam pelayarannya tidak boleh menyimpang kecuali dalam keadaan darurat. Namun undang-undang pelayaran ini tidak menjelaskan apa yang dimaksud dengan:

1. Dikatakan tidak boleh menyimpang tetapi tidak diatur apa yang dimaksud dengan menyimpang.

2. Pasal ini tidak mengatur rumusan delik atau tindak pidana termasuk sanksi pidana. Oleh karena itu, pasal ini sebenarnya adalah pasal yang tidak dapat diterapkan di lapangan khususnya dalam penegakan hukum.
3. Rumusan yang dikandung tidak sesuai dengan ketentuan UNCLOS 1982. Pasal ini menggunakan kalimat "rekomendasi organisasi internasional" untuk penentuan alur laut kepulauan padahal UNCLOS 1982 mengatur mendapatkan "akomodasi organisasi internasional", sehingga penetapan alur laut kepulauan termasuk jumlah alurnya menjadi kewenangan organisasi internasional.

4. Apakah penegak hukum di laut dapat mengetahui bahwa suatu lintas adalah lintas Alur Laut Kepulauan Indonesia (ALKI)? Sebab meskipun sebuah kapal asing berlayar di jalur ALKI, yang pasti kapal tersebut berlayar berdasarkan lintas damai, kecuali apabila terlihat menerbangkan atau mendaratkan pesawat dari/di atas kapal, baru dapat dipastikan bahwa kapal tersebut berlayar berdasarkan ALKI. Selama kapal berlayar berdasarkan lintas damai maka kapal tersebut berhak berlayar menyimpang dari batas-batas jalur ALKI.

\section{Undang-undang Nomor 43 Tahun}

\section{8 tentang Wilayah Negara}

Undang-Undang ini merupakan undangundang organik sebagai pelaksanaan atas Pasal 25A Undang-Undang Dasar 1945 (Amandemen Keempat) yang menyatakan bahwa Negara Kesatuan Republik Indonesia adalah sebuah negara kepulauan yang berciri nusantara dengan wilayah yang batas-batas dan hak-haknya ditetapkan dengan undangundang. 
Dalam Pasal 10 ayat 1f, menyatakan bahwa dalam pengelolaan wilayah negara dan kawasan perbatasan, pemerintah berwenang memberikan izin lintas damai kepada kapalkapal asing untuk melintasi laut teritorial dan perairan kepulauan pada jalur yang telah ditentukan dalam peraturan perundangundangan. Ketentuan ini jelas bertentangan dengan UNCLOS 1982 oleh karena lintas damai adalah hak kapal asing dan lintas damai berlaku di seluruh perairan kepulauan. Hak lintas damai tidak memiliki jalur tertentu. Lintas damai sudah ditetapkan laranganlarangannya.

\section{Peraturan Pemerintah Nomor 36 Tahun 2002 tentang Hak dan Kewajiban Kapal Asing dalam Melaksanakan Lintas Damai Melalui Perairan Indonesia}

Peraturan Pemerintah ini terdiri dari tiga bab dan enam belas pasal. Bab I berisi tentang Ketentuan Umum, Bab II berisi tentang Pelaksanaan Lintas Damai di Laut Teritorial dan Perairan Kepulauan Indonesia, dan Bab III mengatur tentang ketentuan Penutup. Selanjutnya Bab II terbagi dalam tiga sub bab, yaitu (1) Hak dan Kewajiban Kapal Asing, (2) Alur Laut dan Skema Pemisah, serta (3) Penangguhan Lintas Damai.

Menurut pasal 2 dari Peraturan Pemerintah ini bahwa kapal-kapal asing dapat melakukan lintas damai melalui laut teritorial dan perairan kepulauan untuk keperluan melintas dari suatu bagian laut lepas atau zona ekonomi eksklusif ke bagian lain dari laut lepas atau zona ekonomi eksklusif tanpa memasuki perairan pedalaman atau singgah ditempat berlabuh ditengah laut atau fasilitas pelabuhan diluar perairan pedalaman untuk keperluan melintas dari laut lepas atau zona ekonomi eksklusif untuk berlalu ke atau dari perairan pedalaman atau singgah ditempat berlabuh ditengah laut atau fasilitas pelabuhan diluar perairan pedalaman. Berdasarkan ketentuan pasal ini dapat dikatakan bahwa Indonesia hanya mengatur hak lintas damai yang dilakukan kapal asing di Laut Teritorial dan Perairan Kepulauan, sedangkan hak lintas damai di selat internasional belum diatur, padahal Indonesia mempunyai Selat Malaka yang merupakan selat internasional.

Pengaturan lintas damai melalui laut teritorial dan perairan kepulauan dalam Pasal 2 PP ini jelas lebih luas daripada yang diatur dalam Undang-Undang Nomor 6 Tahun 1996 karena sudah memasukkan zona ekonomi eksklusif.

Untuk mengatur lebih lanjut mengenai lintas damai tersebut, Pasal 4 Peraturan Pemerintah memuat ketentuan mengenai kegiatan-kegiatan kapal asing yang dianggap tidak damai yang mengacu pada ketentuan yang terdapat dalam UNCLOS 1982. Hal ini dimaksudkan agar Pemerintah Indonesia dapat mengambil segala tindakan yang diperlukan untuk mencegah terjadinya segala gangguan terhadap keamanan, ketertiban umum dan kepentingan lain didalam laut teritorial dan perairan kepulauannya. 
Permasalahannya adalah Pasal 4 ayat 1a dari Peraturan Pemerintah Nomor 36 Tahun 2002 tidak menyebut secara spesifik tentang kata " Indonesia" setelah kalimat "ancaman atau penggunaan kekerasan terhadap kedaulatan, keutuhan wilayah, kemerdekaan politik". Dengan tidak disebutnya kata Indonesia, semakin menegaskan bahwa Peraturan Pemerintah ini merupakan penulisan kembali ketentuan UNCLOS 1982.

\section{Peraturan Pemerintah Nomor} 37 Tahun 2002 tentang Hak dan Kewajiban Kapal dan Pesawat Udara Asing Dalam Melaksanakan Hak Lintas Alur Laut Kepulauan Melalui Alur Laut Kepulauan yang Telah Ditetapkan

Peraturan Pemerintah ini terbagi dalam lima bab dan dijabarkan dalam enam belas pasal. Bab I tentang Ketentuan Umum, Bab II tentang Hak dan Kewajiban Kapal dan Pesawat Udara Asing dalam Melaksanakan Hak Lintas Alur Laut Kepulauan, Bab III tentang Penetapan Alur Laut Kepulauan yang dapat digunakan untuk Hak Lintas Alur Laut Kepulauan, Bab IV tentang Ketentuan LainLain, dan Bab V tentang ketentuan Penutup.

Peraturan Pemerintah Nomor 37 Tahun 2002 menyatakan, setiap orang bertanggung jawab pada operasionalisasi kapal dan pesawat udara komersial yang kemungkinannya akan mengakibatkan kerugian dan kerusakan yang diderita oleh Indonesia sebagai akibat tidak dipenuhinya ketentuan alur laut kepulauan Indonesia. Selanjutnya negara bendera dari kapal atau negara pendaftaran pesawat udara harus menanggung dan bertanggung jawab terhadap kerugian dan kerusakan yang diderita oleh Indonesia sebagai akibat tidak ditaatinya oleh kapal atau pesawat udara aturan hak lintas alur laut kepulauan.

Selain peraturan diatas, Peraturan Pemerintah Nomor 37 Tahun 2002 tidak mengatur bagaimana seharusnya Indonesia memperlakukan terhadap kapal atau pesawat udara yang tidak mematuhi peraturan perundang-undangan terkait masalah lintas alur laut ini. Kondisi disharmoni seperti pada tabel dibawah ini: 
Tabel 1. Kondisi Disharmoni Hukum Positif Indonesia Terkait Hak Lintas Kapal Asing di Perairan Indonesia

\begin{tabular}{|c|c|c|c|c|c|}
\hline No & $\begin{array}{l}\text { Hukum } \\
\text { Positif }\end{array}$ & Hak Lintas Damai & $\begin{array}{l}\text { Hak Lintas Alur Laut } \\
\text { Kepulauan }\end{array}$ & $\begin{array}{c}\text { Hak } \\
\text { Lintas } \\
\text { Transit }\end{array}$ & UNCLOS 1982 \\
\hline 1 & 2 & 3 & 4 & 5 & 6 \\
\hline 1 & \begin{tabular}{|l|} 
TZMKO \\
1939 \\
Staatblad \\
Nomor 442.
\end{tabular} & $\begin{array}{l}\text { Pasal } 9 \text { dan } 10 \text { dilarang } \\
\text { mengintai dan mengambang } \\
\text { tanpa ijin bagi kapal asing } \\
\text { dgn ancaman pidana } \\
\text { maksimal } 3 \text { bulan penjara } \\
\text { atau denda Rp. } 500 .\end{array}$ & Tidak diatur & $\begin{array}{l}\text { Tidak } \\
\text { diatur }\end{array}$ & $\begin{array}{l}\text { Hak Lintas Kapal } \\
\text { Asing : } \\
\text { A. Hak bagi kapal } \\
\text { asing untuk ber- } \\
\text { layar di perairan } \\
\text { suatu Negara }\end{array}$ \\
\hline 2 & $\begin{array}{l}\text { UU Nomor } \\
17 / 2008 \\
\text { tentang } \\
\text { Pelayaran }\end{array}$ & Tidak diatur & \begin{tabular}{|l} 
Pasal 194 : \\
a. Kapal asing dilarang \\
menyimpang dari \\
alki, tidak dijelaskan \\
apa yang dimaksud \\
menyimpang, tidak \\
ada rumusan delik dan \\
sanksi pidana. \\
b. Agak berbeda dari \\
pasal 22 UNCLOS \\
1982 terkait rekomen- \\
dasi penetapan alur \\
laut oleh organisasi \\
internasional.
\end{tabular} & $\begin{array}{l}\text { Tidak } \\
\text { diatur }\end{array}$ & $\begin{array}{l}\text { B. Memberi ke- } \\
\text { wenangan yuris- } \\
\text { diksi bagi negara } \\
\text { pantai berdasar- } \\
\text { kan kedaulatan } \\
\text { negara di laut. } \\
\text { C. Pasal } 22 \text { unclos } \\
1982 \text { mengatur } \\
\text { bahwa penetapan } \\
\text { alur lintas damai } \\
\text { memperhatikan } \\
\text { rekomendasi } \\
\text { organisasi inter- } \\
\text { nasional yang } \\
\text { kompeten. }\end{array}$ \\
\hline 3 & $\begin{array}{l}\text { UU Nomor } \\
43 / 2008 \\
\text { tentang } \\
\text { Wilayah } \\
\text { Negara }\end{array}$ & $\begin{array}{l}\text { Pasal } 10 \text { ayat } 1 \mathrm{f} \text {, pemerintah } \\
\text { ri memberi ijin lintas damai } \\
\text { bagi kapal asing. }\end{array}$ & Tidak diatur & $\begin{array}{l}\text { Tidak } \\
\text { diatur }\end{array}$ & \\
\hline 4 & $\begin{array}{l}\text { PP Nomor } \\
36 / 2002 \\
\text { tentang } \\
\text { hak lintas } \\
\text { damai bagi } \\
\text { kapal asing } \\
\text { di perairan } \\
\text { indonesia. }\end{array}$ & $\begin{array}{l}\text { Pasal } 2 \text { : lintas damai di } \\
\text { laut teritorial dan perairan } \\
\text { kepulauan. tidak mengatur } \\
\text { lintas damai di selat } \\
\text { internasional (selat malaka). } \\
\text { pasal } 4 \text { (1a) tidak menyebut } \\
\text { kata "indonesia" setelah } \\
\text { kalimat ancaman terhadap } \\
\text { kedaulatan sehingga } \\
\text { menegaskan pp ini hanya } \\
\text { menulis kembali pasal } 19 \\
\text { UNCLOS } 1982 .\end{array}$ & Tidak diatur & $\begin{array}{l}\text { Tidak } \\
\text { diatur }\end{array}$ & \\
\hline 5 & $\begin{array}{l}\text { PP Nomor } \\
37 \text { Tahun } \\
2002 \text { tentang } \\
\text { Hak \& dan } \\
\text { kewajiban } \\
\text { kapal asing } \\
\text { di alur laut } \\
\text { kepulauan } \\
\text { yang telah } \\
\text { ditetapkan }\end{array}$ & Tidak diatur & $\begin{array}{l}\text { Hanya menulis kembali } \\
\text { pasal } 53 \text { unclos } 1982 . \\
\text { pemerintah ri menetapkan } \\
3 \text { alur laut kepulauan } \\
\text { arah utara - selatan, } \\
\text { namun tidak mengatur } \\
\text { bagaimana sanksi bagi } \\
\text { kapal - kapal asing yang } \\
\text { tidak patuh pada PP ini. }\end{array}$ & $\begin{array}{l}\text { Tidak } \\
\text { diatur }\end{array}$ & \\
\hline
\end{tabular}


Ketidak harmonisan peraturan lintas damai maupun hak lintas alur laut mengakibatkan masalah hukum dan kepulauan serta memformulasikan hak dan penegakan hukumnya. Oleh karena itu, sangat penting untuk mengatur keadaan ini melalui pembuatan suatu peraturan perundangundangan yang dengan jelas mengatur masalah penegakan hukum.

Ketidakjelasan didalam kata-kata yang dipergunakan didalam perumusan pasal-pasal tertentu dari beberapa peraturan perundangundangan tersebut diatas mengakibatkan disharmoni/ketidakharmonisan di dalam penafsiran serta penerapannya sehingga menimbulkan gangguan terhadap penegakan hukum. Seperti yang dikatakan Soerjono Soekanto, gangguan terhadap penegakan hukum yang berasal dari undang-undang mungkin disebabkan, karena tidak diikutinya asas-asas berlakunya undang-undang, belum adanya peraturan pemerintah yang sangat dibutuhkan untuk menerapkan undangundang, dan ketidakjelasan arti kata-kata didalam undang-undang yang mengakibatkan kesimpangsiuran didalam penafsiran serta penerapannya. $^{21}$

\section{Simpulan}

Indonesia telah mengatur pemanfaatan hak-hak lintas kapal asing di Perairan Indonesia dalam beberapa peraturan perundang-undangan baik mengenai hak kewajiban yang boleh maupun yang tidak boleh dilakukan oleh kapal asing ketika melaksanakan hak lintas damai atau hak lintas alur laut kepulauan. Akan tetapi apabila ada kapal asing yang tidak mematuhi ketentuan dimaksud, dalam peraturan perundangundangan Indonesia tersebut belum satupun yang mengatur tentang delik ataupun unsurunsur pelanggaran termasuk sanksi hukum pidana yang dapat disangkakan. Kasus kapal Lusitania Espresso yang berbendera Portugal dan Insiden Bawean, serta kasus-kasus lain membuktikan hal tersebut. Oleh karena itu terlalu banyak dan tumpang tindihnya peraturan perundang-undangan yang dibuat berkaitan dengan pemanfaatan hak-hak lintas kapal asing di Perairan Indonesia menyebabkan terjadi kondisi disharmoni dari peraturan perundang-undangan yang ada. Hal ini akhirnya berdampak pada kondisi penegakan hukum di Perairan Indonesia yang belum optimal.

Belum diaturnya secara harmonis peraturan perundang-undangan terkait hak-hak lintas kapal asing di Perairan Indonesia dalam hukum positif Indonesia disebabkan pembuatan peraturan perundangundangan tersebut dilaksanakan tanpa upaya harmonisasi hukum terlebih dahulu terhadap perundang-undangan yang sudah ada.

21 Soerjono Soekanto, Faktor-faktor yang Mempengaruhi Penegakan Hukum, RajaGrafindo Persada, Jakarta, 2012, hlm. 17. 


\section{DAFTAR PUSTAKA}

\section{Buku}

Etty R.Agoes, 1991, Konvensi Hukum Laut 1982, Abardin, Bandung.

Hikmat Israr, 2013, Laksamana Agus

Suhartono dari Blitar ke Cilangkap,

Budaya Media, Bandung.

I Wayan Parthiana, 2003, Pengantar Hukum

Internasional, Mandar Maju Bandung.

Mochtar Kusumaatmadja, 1978, Bunga

Rampai Hukum Laut, Bina Cipta

Bandung.

Hukum Laut Internasional,

1986, Bina Cipta, Bandung.

Kresno Buntoro, 2014, Lintas Navigasi di

Nusantara Indonesia, RajaGrafindo

Persada, Jakarta.

Nina Pane, 2015, Rekam Jejak Kebangsaan

Mochtar

Kusuma-atmadja,

Gramedia, Jakarta.

Peter Mahmud Marzuki, 2013, Penelitian

Hukum, Kencana Prenada Media Group, Jakarta.

Sahono Soebroto, 1983, Konvensi PBB tentang Hukum Laut, Sebuah Tinjauan, Surya Indah, Jakarta.

Salim HS, 2013, Penerapan Teori Hukum

Pada Penelitian Tesis dan Disertasi, RajaGrafindo Perkasa, Jakarta.

Soerjono Soekanto, 2012, Faktor-faktor yang

Mempengaruhi Penegakan Hukum,

RajaGrafindo Persada, Jakarta.

\section{Hasil Penelitian}

Suharyono Kartawijaya, 2015, Harmonisasi Hukum dalam Pemanfaatan Hak Lintas Kapal Asing dan Penegakan Hukum di Perairan Indonesia, Thesis Program Magister Ilmu Hukum pada Fakultas Hukum Universitas Brawijaya, Tidak dipublikasikan.

\section{Peraturan Perundang-undangan}

Hindia Belanda, Staablad Nomor 442/1939

Territoriale Zee en Maritieme Kringen Ordonnantie (TZMKO).

Undang-undang Republik IndonesiaNomor 17 Tahun 1985 tentang Pengesahan United Nations Convention on The Law of The Sea.UNCLOS 1982.

Pengumuman Pemerintah Republik Indonesia tanggal 13 Desember 1957.

Undang-undang Republik Indonesia Nomor 17 Tahun 2008 tentang Pelayaran.

Undang-undang Republik Indonesia Nomor 43 tahun 2008 tentang Wilayah Negara.

United Nations 1982 Convention on the Law of theSea(UNCLOS).

Peraturan Pemerintah Republik Indonesia Nomor 36 Tahun 2002 tentang Hak dan Kewajiban Kapal Asing dalam Melaksanakan Lintas Damai Melalui Perairan Indonesia. 
Peraturan Pemerintah Republik Indonesia Nomor 37 Tahun 2002 tentang Hak dan Kewajiban Kapal dan Pesawat Udara Asing Dalam Melaksanakan San Remo Manual.
Hak Lintas Alur Laut Kepulauan Melalui Alur Laut Kepulauan Yang Telah Ditetapkan. 